\title{
ANALISIS PENINGKATAN INDUSTRI START UP DI BIDANG PENDIDIKAN SELAMA MASA PANDEMI COVID-19
}

\author{
L.Virginayoga Hignasari \\ Program Study Teknik Industri, Fakultas Teknik, Universitas Mahendradatta \\ Jl. Ken Arok No. 12 Peguyangan, Denpasar, Bali 80115 \\ Email : ginahignasari@gmail.com
}

\begin{abstract}
Abstrak - Penelitian ini bertujuan untuk menganalisis peningkatan industri start up di bidang pendidikan selama masa pandemi Covid-19. Penelitian ini merupakan penelitian kualitatif dengan metode studi pustaka. Data yang diperoleh kemudian dianalisis secara deskriptif. Berdasarkan hasil kajian beberapa sumber literatur, di era moderinisasi ini pola kehidupan masyarakat hampir seluruhnya menuju ke arah digitalisasi begitu juga di sektor pendidikan. Adanya pandemi Covid-19 memaksa sektor pendidikan untuk mampu beradaptasi lebih cepat dengan adanya kebijakankebijakan pembatasan kegiatan aktivitas di luar rumah yang bertujuan untuk mencegah penyebaran virus corona. Adanya pembatasan ini menjadikan pembelajaran harus dilakukan secara online dari rumah masing-masing. Keadaan inilah yang menjadikan peluang bagi perusaah start up untuk menghasilkan inovasi-inovasi yang menjadi solusi untuk menjembatani kesenjangan pelaksanaan pembelajaran jarak jauh. Apliksi belajar online merupakan solusi yang tepat untuk memaksimalkan sistem pembelajaran online yang dilakukan selama masa pandemi ini. Ada beberapa indikator yang menentukan keberhasilan sebuah start up, yaitu timming, tim, ide, model bisnis, dan pendanaan (funding). Faktor-faktor tersebut adalah faktor kunci yang menentukan apakah sebuah perusahaan startup akan sukses atau gagal. Selain itu terkait dengan peningkatan jumlah perusaahn start up pendidikan di Indonesia, ada beberapa faktor yang menyebabkan terjadinya hal tersebut. Faktor tersebut diantaranya adalah faktor situasi/kondisi, faktor kebutuhan pengguna dan faktor peluang usaha. Aplikasi digital sangat dibutuhkan sebagai solusi dalam pelaksanaan pembelajaran selama masa pandemi. Sehingga dengan kondisi ini hadirnya start up di bidang pendidikan menjadikan suatu peluang untuk mencari keuntungan. Hal inilah yang mengakibatkan perusahaan start up di bidang pendidikan mulai bermunculan.
\end{abstract}

Kata kunci : covid-19; industri; pandemi; pendidikan; start up

\begin{abstract}
This study aims to analyze the improvement of start-up industry in education during the Covid-19 pandemic. This research is a qualitative research with library study method. The data obtained is then analyzed descriptively. Based on the results of several literature sources, in this modernization era the pattern of people's lives is almost entirely towards digitization as well as in the education sector. The Covid-19 pandemic forced the education sector to be able to adapt more quickly with policies restricting activities outside the home aimed at preventing the spread of the coronavirus. These restrictions make learning must be done online from their homes. This situation makes the opportunity for start-up companies to produce innovations that become solutions to bridge the gap in the implementation of distance learning. Online learning application is the right solution to maximize the online learning system carried out during this pandemic. There are several factors that cause the success of a start-up, namely timing, team, ideas, business model, and funding. These factors are the key factors that determine whether a startup company will succeed or fail. In addition, related to the increasing number of educational start-up companies in Indonesia, there are several factors that cause this. These factors include situation/condition factors, user needs factors and business opportunity factors. Digital applications are needed as a solution in the implementation of learning during the pandemic. So with this condition the presence of start-ups in the field of education makes an opportunity to make a profit. This is what caused start-up companies in the field of education began to emerge.
\end{abstract}

Keywords: covid-19; industry; pandemic; education ; start up 


\section{PENDAHULUAN}

Pandemi Covid-19 telah merubah pola kehidupan manusia di dunia. Hampir semua sektor sangat terdampak dengan adanya pandemi ini. Salah satu sektor yang terdampak adalah sektor pendidikan. Di Indonesia, sejak diumumkanya status darurat Covid-19, seluruh kegiatan belajar mengajar di sekolah ditiadakan. Sesuai kebijakan pemerintah, kegiatan belajar siswa dilakukan di rumah masing-masing secara daring (Hignasari, 2020b). Perubahan yang sangat signifikan tersebut tentunya membuat segala pihak yang terlibat dalam bidang pendidikan termasuk orang tua siswa bekerja lebih keras dari biasanya. Pola pembelajaran yang awalnya dilaksanakan di kelas dengan bimbingan guru, kini dilakukan di rumah masing-masing dengan melibatkan orang tua. Perubahan pola pembelajaran ini memang harus tetap dilakukan untuk masa depan para siswa di Indonesia. Selama pandemi Covid-19 segala aktivitas belajar mengajar formal di sekolah atau universitas, maupun pendidikan nonformal hampir seluruhnya telah dialihkan menggunakan metode virtual.

Dengan kebijakan pemerintah yang mengharuskan semua kegiatan pembelajaran siswa dilakukan di rumah, mengakibatkan anak lebih banyak melakukan aktifitasnya di rumah. Selama pembelajaran dilakukan di rumah secara daring, orang tua sangatlah berperan. Dalam hal ini orang tua berperan dalam memberikan bimbingan dan pengawasan selama pembelajaran daring berlansung (Hignasari, 2020b). Dengan pembelajaran yang dilakukan di rumah selama pandemi ini, kemampuan siswa baik kemampuan kognitif, afektif dan psikomotor dapat dikembangkan sebagaimana mestinya pada saat pembelajaran di kelas. Oleh sebab itu kerjasama antara guru, orang tua dan lingkungan sekitar sangatlah penting bagi perkembangan anak di masa pandemi ini (Hignasari, 2020a)

Pembatasan aktivitas anak di luar rumah tentunya apabila berlangsung dalam jangka waktu yang lama, akan menimbulkan kejenuhan untuk anak. Namun tidak adanya aktivitas anak di luar rumah bukan berarti anak selama diam di rumah tidak melakukan aktivitas belajar. Media pembelajaran merupakan salah satu alternatif untuk mengatasi permasalahan tersebut. Media pembelajaran adalah media yang dirancang secara khusus untuk merangsang pikiran, perasaan, perhatian, dan kemauan peserta didik sehingga terjadinya proses pembelajaran. Media pembelajaran memuat informasi yang dapat berupa pengetahuan maupun menjadi sarana bagi siswa untuk melakukan aktivitas belajar (membaca, mengamati, mencoba, mengerjakan soal, menjawab pertanyaan, dan lain-lain). Media pembelajaran bukan sekedar benda fisik, namun segala sesuatu yang sudah berisi materi pembelajaran, sehingga memungkinkan seseorang memanfaatkannya untuk belajar guna memperoleh pengetahuan, keterampilan, atau perubahan sikap (Efendi, 2018). Secara umum manfaat media dalam pembelajaran adalah memperlancar interaksi guru dan siswa, dengan maksud untuk membantu siswa belajar secara optimal meskipun saat siswa belajar dari rumah. Dengan bantuan media yang menarik, siswa akan lebih mudah untuk memahami materi pelajaran dan hal ini akan berdampak positif terhadap hasil belajar siswa terutama di masa pandemi Covid-19.

Dengan adanya kebijakan yang mengharuskan pembelajaran dilakukan secara virtual, maka teknologi adalah salah satu cara yang dapat dimanfaatkan untuk menyelesaiakan kesenjangan yang terjadi selama masa pandemi Covid-19. Untuk menjembatani keadaan ini, penggunaan platform pembelajaran daring pun semakin melonjak. Hal ini berdampak positif bagi startup yang bergerak di sektor pendidikan berbasis daring. Berbagai upaya dilakukan untuk memajukan pendidikan Indonesia di masa pandemi ini. Semua elemen masyarakat bergerak, tak terkecuali para pemuda Indonesia. Mereka tergerak untuk membuat startup pendidikan yang bertujuan untuk meningkatkan kualitas pendidikan di Indonesia. Berikut ini beberapa startup karya anak bangsa yang bertujuan untuk meningkatkan mutu pendidikan Indonesia yaitu Quipper Video, Ruang Guru, Indonesia X, Haruka Edu, Arkademy, Bahaso, Squline, Zenius, Kalase, Quintal Meja Kita (Namira, 2019).

Di era digitalisasi ini dan dengan ditambah adanya pandemi Covid-19, sektor pendidikan 
mau tudak mau harus beradaptasi dengan cepat. Kegiatan pembelajaran yang awalnya dilakukan tatap muka di sekolah, kini harus dilakukan di rumah masing-masing. Agar pembelajaran dapat berjalan dengan baik perlu adanya bantuan yaitu dalam hal ini adalah bantuan teknologi. Teknologi mampu memberikan solusi dalam pelaksanaan pembelajaran jarak jauh secara daring. Kebutuhan akan adanya teknologi di bidang pendidikan membuat hal ini menjadikan lahan bisnis baru yang sedang berkembang. Start Up di bidang pendidikan tidak kalah pentingya dengan start up di bidang ekonomi bisnis. Karena SDM yang unggul berasal dari kualitas pendidikan yang unggul pula. Melihat begitu pentingya keberadaan industri start up di bidang pendidikan terutama di masa pandemi ini, berdasarkan hal tersebut pada penelitian ini akan dibahas mengenai bagaimana peningkatan bisnis starup bidang pendidikan di Indonesia. Adapun tujuan dari penulisan ini adalah untuk mengetahui fakor penyebab meningkanya industri start up di bidang pendidikan di masa pandemi Covid-19.

\section{METODE PENELITIAN}

Penelitian ini merupakan penelitian kualitatif dengan menggunakan metode studi Pustaka. Data-data yang digunakan dalam penelitian ini berupa data-data primer dan data sekunder yang di dapat dari beberapa sumber baik secara lisan, tertulis maupun secara online. Kajian pustaka dalam suatu penelitian ilmiah adalah salah satu bagian penting dari keseluruhan langkah-langkah metode penelitian. Cooper dalam Creswell mengemukakan bahwa kajian pustaka memiliki beberapa tujuan yakni; menginformasikan kepada pembaca hasil hasil penelitian lain yang berkaitan erat dengan penelitian yang dilakukan saat itu, menghubungkan penelitian dengan literatur-literatur yang ada, dan mengisi celahcelah dalam penelitian-penelitian sebelumnya. Anderson mengemukakan bahwa kajian pustaka dimaksudkan untuk meringkas, menganalisis, dan menafsirkan konsep dan teori yang berkaitan dengan sebuah proyek penelitian (Pebriana, 2017). Data-data yang telah terkumpul kemudian dianalisis secara deskriptif untuk mengatahui faktor apa saja yang mengakibatkan peningkatan kuantitas dari industri start up pendidikan di Indoneisa.

\section{HASIL DAN PEMBAHASAN \\ Industri Start Up Bidang Pendidikan di Indonesia}

Era digital berpengaruh terhadap pola kebutuhan masyarakat termasuk dalam bidang pendidikan. Perkembangan startup di Indonesia memang cukup pesat, namun meningkatnya perkembangan jumlah startup tersebut juga sebanding dengan angka kegagalan yang menimpa startup. Faktanya, angka kegagalan startup di seluruh dunia bisa mencapai $90 \%$. CB Insight merilis 20 hal yang menjadi penyebab kegagalan startup dalam membangun bisnisnya, 5 diantaranya paling umum ditemukan sebagai penyebab kegagalan startup dari internal perusahaan yaitu: (1) produk yang tidak dibutuhkan pasar (42\%), (2) terlalu banyak "bakar uang" (29\%), (3) tim yang tidak solid (23\%), (4) kalah dalam kompetisi (19\%), serta (5) pricing/cost issues (18\%) (Efendi, 2018).

Startup merupkan istilah dari perusahaan rintisan. Dengan kata lain, startup artinya perusahaan yang baru masuk atau masih berada pada fase pengembangan atau penelitian untuk terus menemukan pasar meupun mengembangkan produknya. Saat ini, istilah perusahaan startup biasanya mengacu pada perusahaan-perusahaan yang layanan atau produknya berbasiskan teknologi. Perkembangan perusahaan rintisan di Indonesia memang cukup kencang dalam beberapa tahun belakangan ini. Karena pesatnya perkembangan startup, seringkali menciptakan disrupsi ekonomi (Idris, 2020). Dikutip dari Kompas TV, sebuah usaha bisa disebut sebagai startup kalau memiliki minimal 3 faktor yaitu pendiri atau founder, investor atau pemilik dana, dan produk atau layanan. Startup kemudian bisa menjadi kategori unicorn apabila nilai korporasinya sudah melebihi 1 miliar dollar AS atau setara dengan Rp 14 triliun (kurs Rp 14.000). Startup belum tentu bisa berhasil bahkan menjadi unicorn tanpa investor yang disebut sebagai angel investor atau malaikat pemberi dana. Angel investor adalah pihak yang paling awal berinvestasi dan berani mengambil risiko terhadap konsep produk startup dengan catatan saat investor lain belum berani melakukannya. Karena masuk paling awal, angel investor biasanya menuntut detail dan akurasi 
terhadap produk antara lain aplikasi startup, strategi pasar, dan target pasar. Ketika startup yang didanainya berhasil, maka angle investor akan jadi pemegang saham terbesar. Sebaliknya jika gagal maka dana yang sudah digelontorkan akan lenyap begitu saja (Idris, 2020).

Startup merupakan perusahaan baru yang sedang dikembangkan atau belum lama beroperasi atau biasa disebut sebagai perusahaan rintisan. Untuk mempermudah menemukan makna dari starup berikut karakteristik sebuah perusahan bisa dikatakan dengan sebutan startup.

1. Usia perusahaan

Jika ibu hamil ibarat sebuah perusahaan, maka anak yang baru lahir bisa ibaratkan bisnis yang baru akan di jalankan baru berumur kurang dari 3 tahun.

2. Jumlah karyawan minimalis

Pada umumnya startup memiliki jumlah karyawan yang sedikit kurang lebih 30 orang.

3. Sumber daya manusia multitasking

Meskipun berawal memilki karyawan yang relatif sedikit namun karyawan memiliki talenta terbaik dan ahli yang berada di bidangnya masing-masing.

4. Semangat kerja tinggi

Selain itu, karyawan yang bekerja di startup umumnya berasal dari kaum milenial yang berusia muda dan melek teknologi. Biasanya perusahaan ini didirikan oleh anak muda berkisar 20 sampai 35 tahun. Sehingga dengan rentang usia tersebut masih memiliki banyak keinginan yang selalu ingin dikejar yang diiringi dengan semangat yang menggebu-gebu.

5. Umumnya bergerak di bidang teknologi

Meski pengertian sesungguhnya sebuah startup, namun tidak harus selalu di bidang teknologi. Seringkali kita temui beberapa startup yang ada saat ini pasti memiliki di bidang teknologi.

6. Website menjadi sarana utama

Perusahaan startup pastinya memiliki website pribadi untuk menjalankan segala pekerjaannya, yaitu untuk menawarkan dan mempromosikan produk yang dijual. Bisnis yang mereka jalankan meliputi jasa online yang pengoperasiannya menggunakan aplikasi pada yang selalu terhubung dengan website perusahaan itu sendiri.

7. Konsumen startup adalah prioritas

Target dari berdirinya sebuah startup adalah untuk memperoleh konsumen sebanyakbanyaknya. Oleh karena itu startup selalu menghadirkan inovasi-inovasi untuk memanjakan setiap konsumen yang dimilikinya (Setiawan, 2019).

Berkembangnya dunia digital berpengaruh terhadap cara belajar siswa dengan optimalisasi penggunaan perpustakaan digital dalam memenuhi kebutuhan atas keingintahuannya terhadap materi ajar. Seiring berkembangnya teknologi digital di Indonesia dengan menyadari kebutuhan siswa yang berada pada kebijakan kurikulum yang menghendaki penggunaan jam belajar sistem fullday school. Maka hadirlah beragam media alternatif untuk menjangkau siswa tanpa melanggar sistem justru sebagai alat pemenuhan kebutuhan siswa dalam belajar lebih efisien dan efektif. Yaitu berkembangnya startup pendidikan. Startup pendidikan lebih banyak berupa bimbingan belajar secara online dengan menghadirkan guru secara virtual dalam bentuk video seperti yang dilakukan oleh Quipper Video dan Ruang Guru. Adapula yang menggunakan hanya audio dengan penjelasan secara verbal seperti Zenius. Dengan jumlah siswa di Indonesia rata-rata mencpaai 45 juta/tahun tentu merupakan jaminan dan peluang bagi penggiat startup pendidikan (edutech) ditambah dengan digitalisasi yang tidak bisa ditinggalkan. Siswa di Indonesia hampir keseluruhannya sudah memiliki smartphone sebagai media komunikasi, hiburan, dan belajar. Bahkan terdapat pola sekolah di rumah atau sering disebut Home schooling dilakukan secara online seperti Kelase. Berikut startup pendidikan (edutech) di Indonesia:

1. Quipper Video

Quipper Video merupakan edutech Perusahaan Jepang yang berdiri pertama kali di Inggris dan membuka cabangnya di Indonesia. Quipper Video termasuk edutech yang berkonsentrasi terhadap kualitas konten dengan menyesuaikan sistem dengan kurikulum yang diterapkan di Indonesia. sehingga dapat dikatakan bahwa Quipper 
Video dapat digunakan siswa sebagai The second School.

\section{Ruang Guru}

Ruang Guru merupakan startup yang dapat dikatakan sebagai startup (edutech) yang sejauh ini paling komplit dengan menggabungkan berbagai fitur yang ada di hampir seluruh edutech yanga ada dalam satu kemasan. Seperti RuangLes, platform tanya jawab dengan guru secara online bernama RuangLesOnline dan Digital Bootcamp, platform ujian (tryout) online yang disebut RuangUji, hingga kumpulan video dan materi edukasi dalam fitur RuangBelajar. Ruang guru pun cerdik dalam hal pemasaran dengan menggunakan tokoh hiburan yang sedang digandrungi para pelajar. Tentunya dengan kualitas latarbelakang pendidikan yang kualitasnya tinggi sehingga hal tersebut menjadi refresentatif dari edutech yang ditawarkan. Namun dari segi konten, Ruang Guru memang menggunakan animasi namun tidak berjenis animasi graphic visual.

\section{Zenius}

Zenius merupakan edutech yang berisi fiturfitur pembahasan soal dalam menghadapi menghadapi tes masuk perguruan tinggi, menghadapi ujian nasional, ujian-ujian sekolah, serta alat-alat belajar yang dapat diakses kapanpun dan di manapun secara online. Meskipun diakses online, Zenius dapat diakses juga secara offline yang terdapat didalamnya modul dan video tutorial. 178 Berbeda dengan Ruang Guru dan Quipper Video, Zenius hanya menjelaskan materi atau soal-soal dengan audio tanpa menampilkan tutornya.

4. Kelase

Kelasa merupakan edutech yang mirip dengan media sosial sebagai ruang baru interaksi masyarakat di sekolah di masyarakat digital. Antara guru, murid, orangtua, dan staff sekolah. Kelase memiliki platform belajar online secara mandiri dan meluas.

5. Quintal

Merupakan startup yang berdiri sejak juli 2016 dengan konsen terhadap pengelolaan kegiatan belajar mengajar di sekolah dengan menggunakann software khusus. keunggulan karena menggabungkan Sistem Informasi Sekolah (SIS) dan Learning Management System (LMS). Meskipun tidak sebesar startup lainnya, Quintal berhasil menjaring sekitar 2000 pengguna dengan memanfaatkan 5 sekolah di sekitar jakarta. Quintal bertujuan untuk mendorong sekolah untuk melakukan proses belajar-mengajar secara online melalui penggunaan Quintal sebagai alat untuk membagikan materi, tugas, serta ulangan secara online. Selain efisien untuk siswa, guru pun dimudahkan dalam memproses hasil belajar siswa. Fitur utama pada startup ini adalah fitur input nilai dan data absensi para siswa. Sehingga orang tua siswa dapat secara langsung mendapatkan pemberitahuan mengenai jadwal ulangan, serta kegiatan siswa termasuk bolos atau tidak dalam proses pembelajaran di sekolah.

6. HarukaEdu

HarukaEdu merupakan edutech yang berkonsentrasi terhadap pelajar tingkat strata satu dengan berhasil bekerjasama dengan beberapa lembaga pendidikan tinggi seperti President University, Sekolah Tinggi IImu Ekonomi Indonesia, ESQ Business School, London School of Public Relations, Universitas Wiraswasta Indonesia dan Institut Teknologi Harapan Bangsa. Salah satu manfaat yang penulis cermati dengan berkembangnya edutech adalah memastikan pelajar di seluruh Indonesia mendapatkan pengetahuan yang sama tanpa adanya dikotomi pelajar jawa ataupun pelajar luar jawa yang sebelum era digital sangat dirasakan berbeda (Efendi, 2018).

\section{Analisis Faktor Meningkatnya Industri Start Up Di Bidang Pendidikan}

Baik startup maupun perusahaan konvensional sebenarnya tidak ada perbedaan jika dilihat dari aspek legal. Semua perusahaan, baik startup maupun perusahaan konvensional adalah berbadan hukum. Berikut ini beberapa perbedaan mencolok antara startup dengan perusahaan biasa. 
Tujuan keuntungan

- Startup adalah perusahaan yang berisiko tinggi karena cenderung masih menemukan model bisnis yang pas dan terus mencari pasar. Pertumbuhan perusahaan adalah tujuan utama dari startup meski perusahaan harus terus membakar uang di periode awal.

- Perusahaan konvensional lazimnya berdiri untuk sesegera mungkin fokus bisa mendapatkan profit. Tujuannya untuk memberikan keuntungan kepada pemiliknya (Idris, 2020).

Pendanaan

- Founder startup relatif hanya mengeluarkan dana saat merintis bisnis dengan harapan ada investor yang datang untuk memberikan dana segar, jika dipercaya investor, startup bisa menerima dana jutaan hingga miliaran dollar.

- Perusahaan konvensional pendanaannya berasal dari satu atau lebih pemilik perusahaan, di mana pendanaan juga bisa berasal dari hasil profit yang diputar kembali (Idris, 2020).

\section{Struktur organisasi}

- Operasional perusahaan startup cenderung ditentukan sepenuhnya oleh founder atau manajemen perusahaan. Sementara investor tak banyak mencampuri bisnis startup. Investor biasanya hanya terlibat pada keputusan-keputusan strategis.

- Dalam perusahaan konvensional, jalannya perusahaan sangat dipengaruhi oleh kehendak pemilik perusahaan, entah secara langsung atau tidak langsung. Bahkan banyak perusahaan yang pemodalnya atau pemiliknya masuk dalam manajemen perusahaan, sesuatu yang hampir sulit sekali ditemukan pada perusahaan strartup (Idris, 2020).

Bill gross melakukan riset dengan melakukan analisis 200 startup yang sukses dan gagal dari startup yang berada didalam idealab dan beberapa startup di luar idealab seperti Uber, AirBnb, YouTube, dan lainnya, mengungkapkan ada 5 indikator yang menentukan kesuksesan sebuah startup. Kelima indikator tersebut adalah timing, team, idea, bisnis model, dan funding (Dessi, 2020). Dari 200 startup tersebut, 42 persen kesuksesan mereka dipengaruhi oleh faktor timing yang tepat. Kemudian diikuti oleh faktor team sebanyak 32 persen, idea 28 persen, bisnis model 24 persen dan funding 14 persen (Jaya et al., 2017). Dalam merintis sebuah perusahaan startup ada beberapa indikator yang menentukan kesuksesan dari perusahaan tersebut. Faktor tersebut diantaranya adalah.

\section{Timming}

Timming adalah pemilihan waktu atau momentum yang tepat untuk melakukan sesuatu. Timing merupakan faktor utama dalam startup yang telah dibuktikan oleh sejumlah startup yang sukses. Bill memberikan contoh bagaimana timing sangat mempengaruhi startup, pertama adalah AirBnb, banyak orang beranggapan tidak akan ada orang yang akan mau menyewakan rumah mereka ke orang asing, anggapan itu ternyata salah. AirBnb muncul di saat orangorang sangat memerlukan pendapatan tambahan dan salah satu cara yang disediakan oleh AirBnb adalah dengan menyewakan tempat tinggal mereka. Kedua adalah UBER, Bill mengungkapkan bahwa UBER muncul saat kebutuhan akan transportasi sangat tinggi dan juga banyak supir yang ingin mendapat pendapatan tambahan (Jaya et al., 2017). Di Indonesia khususnya di bidag pendidikan, Ruang Guru merupakan salah satu start up yang sedang naik daun terutama di masa pandemi Covid-19 ini. Cita-cita awal didrikanya startup ini adalah untuk meningkatkan kualitas guru di Indonesia. Hal itu tentunya akan berdampak pada mutu pendidikan di Indonesia, mengingat guru adalah ujung tombak pendidikan. Hingga saat ini Ruangguru telah memiliki enam juta pengguna dan sempat mendapatkan penghargaan 30 Under 30 Asia dari Majalah Forbes. Kemunculanya Ruang Guru di Publik memanglah sangat tepat. Disaat masyarakat Indonesia memerlukan sesuatu solusi dari sistem pembelajaran secara daring di masa pandemi ini, Ruang Guru hadir sebagai solusi yang dapat memberikan pembelajaran secara daring kepada siswa selain pembalajaran yang diterima dari sekolah masing-masing. 


\section{Tim}

Setiap perusahaan berpikir bahwa sudah bekerja dengan baik dalam mengelola sumber daya manusia yang dimiliki (Uzzaman, 2015). Perusahaan akan berkata karyawan adalah aset yang paling berharga, namun kebanyakan perusahaan tidak benar-benar melakukannya. Gilt sebuah perusahaan situs belanja diskon merupakan contoh dari sebuah startup yang sepenuhnya mengandalkan tim. Kevin ryan, founder Gilt menambah dua co-founder yang kemudian mengubah masa depan perusahaan, kehadiran Alexis Mayback, salah seorang founding member eBay, memberikan Gilt jaringan bisnis untuk menjangkau merek-merek terkenal agar bergabung dengan situsnya. Alexandra Wilson, yang sebelumnya bekerja di Louis Vuitton dan Bvlgari memiliki keterampilan negosiasi dan pengetahuan yang diperlukan untuk menjadi sebuah ECommerce yang sukses. Gilt 14 berhasil mencapai US $\$ 30$ juta dalam tahun pertamanya. Kisah Gilt mengambarkan dengan jelas pentingnya tim bagi sebuah startup. Kualitas tim merupakan salah satu tolak ukur penting untuk mempercayakan modalnya dalam perusahaan tersebut atau tidak. Bill gross pendiri idealab yang juga seorang serial enterprener meneliti berdasarkan pengalamannya ada 5 indikator yang menentukan kesuksesan sebuah startup, menempatkan team pada posisi penting kedua setelah timing. Ross Kimbarovsky pendiri CrowdSPRING, sebuah startup yang bergerak dibidang crowd sourcing design mengatakan sebuah tim yang baik adalah yang bersemangat, fleksibel, dan jujur (Jaya et al., 2017). Di Indonesia bisinis startup yang bergerak di bidang pendidikan mulai menjamur. Ada beberapa bisnis start up di bidang pendidikan diantaranya adalah Ruang Guru, Indonesia X, Haruka Edu, Arkademy, Bahaso, Squline, Kalase, Meja Kita (Namira, 2019)Dari semua bisnis start up tersebut dikelola oleh tim yang solid. Tim merupakan kekuatan yang utama dalam membanguan sebuah bisnis. Dengan manajemen tim yang baik, bisnis akan tetap eksis dan akan terus berkembang.
3. Ide

Munculnya sebuah perusahaan start up harus dengan menyuguhkan sesuatu ide atau gagasan yang baru. Kemunculan perusahaan start up haruslah bertujuan untuk memberikan solusi dari permasalahan yang dihadapi oleh masyarakat banyak. Ide merupakan salah satu kata kunci keberhasilan sebuah perusahaan start up. Inovasi yang dihadirkan oleh perusahaan start up haruslah mampu memberikan manfaat yang signifikan bagi pengguna dalam hal ini adalah masyarakat. Tujuan dari sebuah bisnis adalah mendapatkan keuntungan yang tinggi dengan cara yang lebih efektif dan efisien. Startup merupakan salah satu perusahaan digital yang mengutamakan kecepatan dan ketepatan dalam berbisnis, tetapi startup dirancang untuk menciptakan produk dan jasa ditengah ketidakpastian yang ekstrim (Ries, 2011). Startup dirancang untuk menemukan model bisnis yang tepat dapat berulang dan berskala(Carter, 2011).

\section{Model Bisnis}

Model bisnis merupakan alat bantu yang menjelaskan bagaimana suatu organisasi menciptakan, memberikan, dan menangkap suatu nilai tambah. Sebuah startup memerlukan alat ini untuk memberikan pandangan yang menyeluruh akan proses bisnis yang akan direncanakan, atau bahkan menjelaskan bisnis yang sedang berjalan. Banyak bisnis yang baru mulai mengalami banyak kendala selama operasionalnya. Model bisnis dapat membantu menganalisa masalah dan mencari solusinya. Startup baru dapat menggunakan model bisnis untuk merancang bentuk yang sesuai dengan kondisi startupnya. Model bisnis merupakan suatu model yang menjelaskan tentang bagaimana suatu perusahaan bergerak dalam mencapai keuntungan. Model ini diibaratkan sebagai sebuah kendaraan yang dibangun oleh perusahaan dalam rangka mengantar mereka ke tempat tujuan. Sebuah startup memerlukan model bisnis yang tepat untuk meningkatkan daya saing dan mencapai tujuan akhirnya (Uzzaman, 2015). Faktor pendukung kesuksesan startup adalah model bisnis yang baik, tiga keuntungan memiliki model bisnis yang baik, yaitu mampu memberikan pandangan kepada 
perusahaan mengenai bagaimana respon pasar terhadap produk yang dimiliki, melemahkan daya saing perusahaan kompetitor, dan mendorong persekutuan dengan perusahaan kompetitor (mutualisme) dalam menciptakan produk yang mampu menjawab kebutuhan pasar. Keuntungan-keuntungan tersebut mampu menjadi kunci bagi perusahaan dalam memenangkan persaingan di pasar.

\section{Pendanaan (Funding)}

Rekanan bisnis dan investor mengetahui bahwa organisasi sebuah perusahaan berkaitan erat dengan kesuksesannya. Jika perusahaan memiliki organisasi yang buruk, pihak luar tidak akan mempercayai. SDM startup yang baik, kualitas tim berbanding lurus dengan minat investor untuk menanam modal selain nama besar perusahaan (Uzzaman, 2015). Bill mengungkapkan bahwa startup sekarang sangat mudah memperoleh investasi. Asalkan mereka memiliki tim dan traksi yang kuat, mendapat investasi bukanlah yang yang mustahil (Dessi, 2020).

Berdasarkan hasil analisis di atas, maka dapat dijabarkan faktor-faktor yang menyebabkan meningkatnya industri start up di bidang pendidikan di Indonesia adalah :

- Faktor Situasi / Kondisi

1. Adanya Era modernisasi yang menuntut perubahan pola kehidupan kearah digitalisasi termasuk di sektor pendidikan.

2. Adanya pembatasan aktifitas di luar rumah saat masa pandemi ini membuat pembelajaran formal dilakukan secara online.

- Faktor Kebutuhan Pengguna

1. Pembelajaran secara digital lebih menarik minat siswa, karena sesuai dengan karakteristik siswa di era milenial yang cenderung lebih suka pada hal-hal yang bernuansa digital dan praktis.

2. Aplikasi online merupakan salah satu solusi dalam pelaksanaan pembelajaran secara online.

3. Penggunaan aplikasi belajar online merupakan salah satu alternatif untuk meningkatkan kegiatan pembelajaran anak selama dirumah.
4. Aplikasi belajar online sangat membantu siswa apabila siswa mengalami kesulitan saat megerjakan tugas sekolah yang diberikan guru.

5. Aplikasi belajar online dapat memberikan tambahan wawasan dan pemahaman siswa terhadap mata pelajaran yang di ajarkan di sekolah.

- Faktor Peluang Usaha

1. Target pasar adalah orang-orang yang berkecimpung di dunia pendidikan baik itu siswa, pengajar ataupun pihak-pihak yang terlibat di dalam proses kegiatan pembelajaran. Oleh sebab itu jika dilihat dari karakteristik calon pengguna dapat disimpulkan bahwa target pengguna sangatlah besar. Sehingga dengan banyaknya calon pengguna tentunya akan berdampak pada untung yang tinggi.

2. Aplikasi digital sangat dibutuhkan sebagai solusi dalam pelaksanaan pembelajaran selama masa pandemi. Sehingga dengan kondisi ini hadirnya start up di bidang pendidikan menjadikan suatu peluang untuk meningkatkan keuntungan.

3. Perusahaan start up merupakan perusahaan yang sebagian besar bergerak di bidang digitalisasi yang memang sesuai dengan perkembangan era moderinisasi ini. Sehingga produk yang dihasilkan lebih muda diterima masyarakat, karena sesuai dengan tuntutan hidup di masa kini.

\section{PENUTUP}

Di masa pandemi ini, kegiatan pendidikan anak sekolah masih dilakukan melalui daring di rumah masing-masing. Perkembangan kemampuan anak di masa pandemi ini tidak dapat dipandang sebelah mata. Orang tua dan guru harus bekerja sama menciptakan suatu pembelajaran yang ekektif untuk anak. Dalam menjembatani hal ini, penggunaan aplikasi merupakan salah satu solusi agar pembelajaran daring dapat terlaksana secara maksimal. Hal ini merupakan salah satu faktor pemicu tumbuhnya perusahaan perusahaan start up di bidang pendidikan. Munculnya start up bidang pendidikan memiliki tujuan utama yaitu untuk menignkatkan kualitas pendidikan di Indonesia terutama di masa 
pandemi ini. Meskipun memiliki tujuan untuk meningkatkan kualitas pendidikan di Indonesia, namun sebuah berdirinya perusahaan tentunya memiliki tujuan untuk mendapatkan keuntungan. Berhasil atau tidaknya perusahaan start up ditentukan oleh beberapa indikator yaitu timing, team, idea, bisnis model, dan funding. Berdasarkan hasil analisis maka terdapat beberapa faktor yang menyebabkan meningkatnya industri start up di bidang pendidikan di Indonesia adalah : faktor situasi/kondisi, faktor kebutuhan pengguna dan faktor peluang usaha. Masa Pandemi mengharuskan kegiatan pembelajaran dilakukan secara daring. Adanya pembatasan aktifitas di luar rumah saat masa pandemi ini membuat pembelajaran formal dilakukan secara online. Penggunaan aplikasi belajar online merupakan salah satu alternatif untuk meningktakan kegiatan pembelajaran anak selama dirumah, Aplikasi digital sangat dibutuhkan sebagai solusi dalam pelaksanaan pembelajaran selama masa pandemi. Sehingga dengan kondisi ini hadirnya start up di bidang pendidikan menjadikan suatu peluang untuk meningkatkan keuntungan. Hal inilah yang mengakibatkan perusahaan start up di bidang pendidikan mulai bermunculan.

\section{DAFTAR PUSTAKA}

Dessi, C. (2020). 5 Top Indicators for Startup Success, According to this TED Talk. The biggest reason why startups succeed today. Inc.Com. https://www.inc.com/chris-dessi/thisted-talk-explains-the-5-reasons-why-startupssucceed.html

Efendi, N. M. (2018). Revolusi Pembelajaran Berbasis Digital (Penggunaan Animasi Digital Pada Start Up Sebagai Metode Pembelajaran Siswa Belajar Aktif). Habitus: Jurnal Pendidikan, Sosiologi, Dan Antropologi, 2(2), 173-182.
Hignasari, L. V. (2020a). Analisis Peluang Usaha Pembuatan Alat Permainan Edukatif Anak Selama Masa Pandemi Covid-19. Jurnal IImiah Vastuwidya, 3(2), 14-22. https://doi.org/10.47532/jiv.v3i2.209

Hignasari, L. V. (2020b). Impact Analysis of Online Learning Toward Character Education of Elementary School Students In The New Normal Era. In New Normal: Idealism and Implementation in Indonesia and Philippines (pp. 225-244).

Idris, M. (2020). Apa itu startup dan perbedaanya dengan perusahaan konvensional. Kompas.Com. https://money.kompas.com/read/2020/10/21/0 93719826/apa-itu-startup-dan-perbedaanyadengan-perusahaan-konvensional?page=all

Jaya, M. A., Ferdiana, R., \& Fauziyati, S. (2017). Analisis Faktor Keberhasilan Startup Digital di Yogyakarta Mardi Arya Jaya 1, Ridi Ferdiana 2 , Silmi Fauziati 3. Jurnal.Umk.Ac.ld, 4(1), 167-173.

https://jurnal.umk.ac.id/index.php/SNA/article/ view/1261

Namira, I. (2019). Mencerdaskan Bangsa, Ini 8 Startup yang Bergerak di Bidang Pendidikan. Idntimes.Com; idntimes.com. https://www.idntimes.com/tech/trend/izzanamira-1/startup-indonesia-di-bidangpendidikan $/ 8$

Pebriana, P. H. (2017). Analisis Penggunaan Gadget terhadap Kemampuan Interaksi Sosial pada Anak Usia Dini. Jurnal Obsesi: Jurnal Pendidikan Anak Usia Dini, 1(1), 1. https://doi.org/10.31004/obsesi.v1i1.26

Setiawan, H. (2019). Pengertian Startup Adalah, Sejarah Singkat dan Karakteristiknya. Liputan6.Com.

Uzzaman, A. (2015). StartupPedia. Bentang Pustaka. 